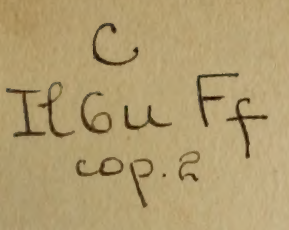

\title{
In MHenturiam
}

\section{Stephen Alfred Thrbes}

\author{
1844-1931
}





\section{Return this book on or before the}

\section{Latest Date stamped below.}

Theft, mutilation, and underlining of books are reasons for disciplinary action and may result in dismissal from the University.

University of Illinois Library

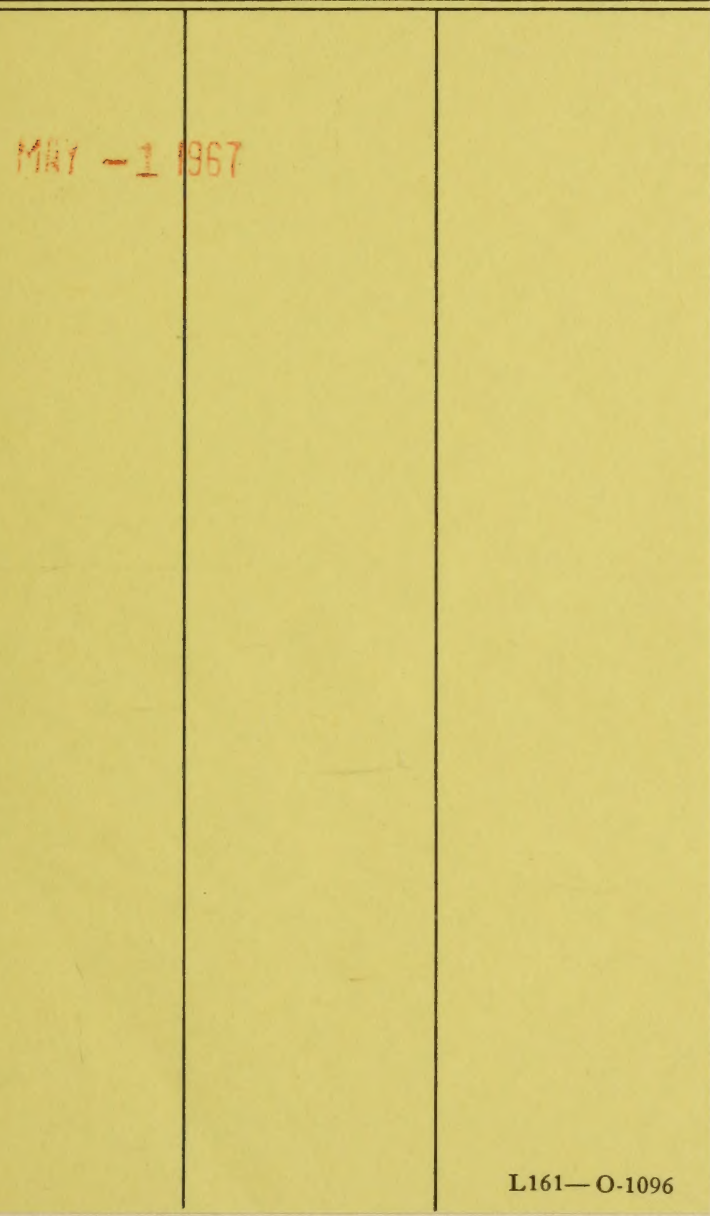





\section{THE LBRARY \\ OF THE UIIVERSITY OF ILLIMOIS}




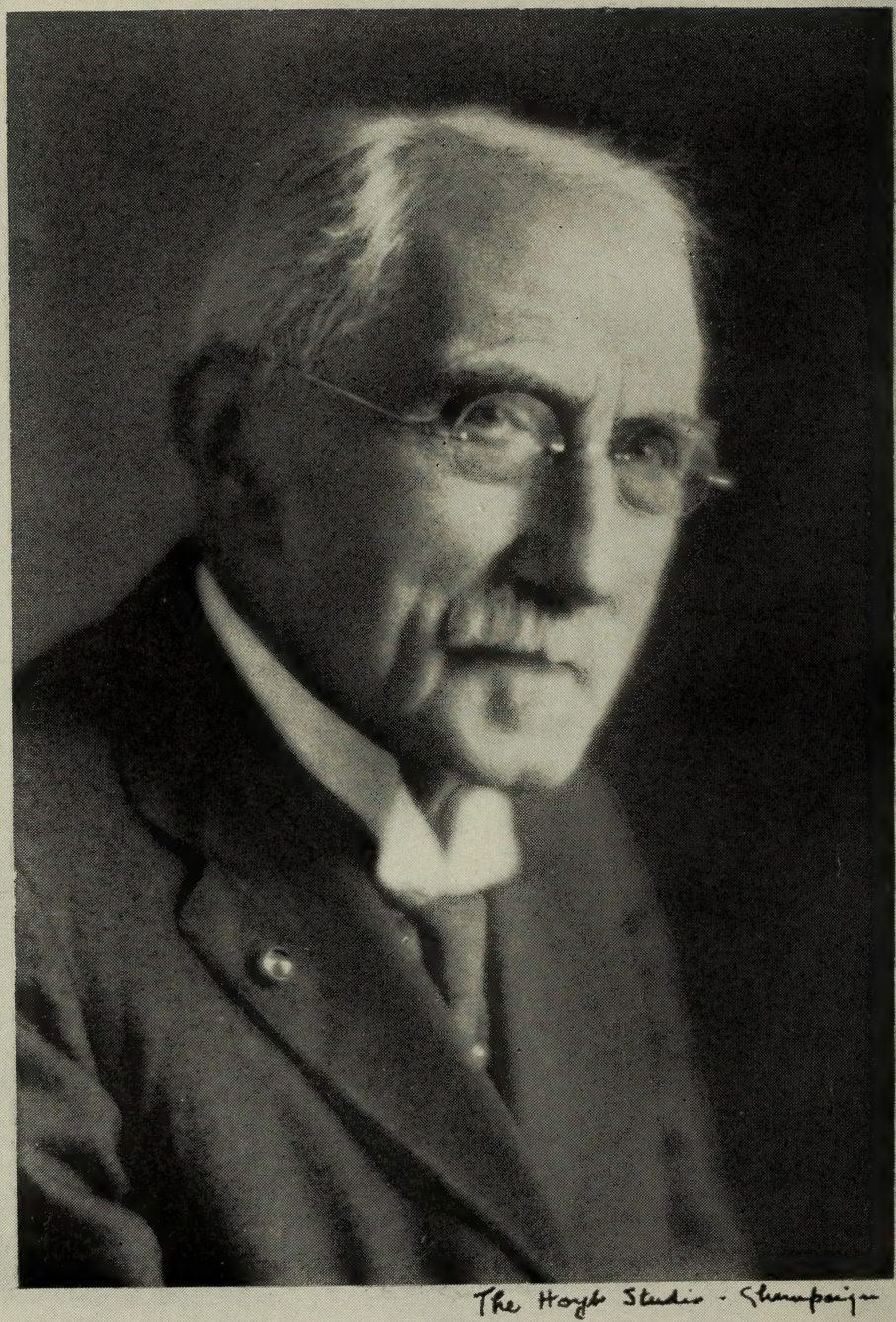

Stephen Alfred Forbes, Ph.D., LL.D.

I $844^{-1} 930$ 


\section{fillemural af the fitneral}

Serutes far

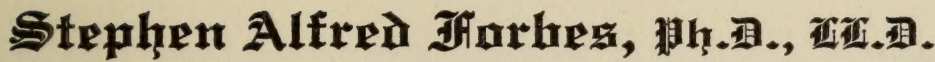

Chief, \$tate Natural Ofitstory \$uruey

Arnfegsar af Entamnlagy, Temerttus

Hnituergity af Xllinats

\section{THE LBRARY THE THE \\ UIN 4 \& 1930 \\ UNIVERSITY OF HLINOIS}

Smith Altenturial 缩all

Zntuetsty of fllinnis

Suniay, flltarch 16, 1930

3 n'rlark

Jithana, Xllinnis 



\section{Stephen Alfred Grobeg}

\section{Chranalugy}

Born at Silver Creek, Stephenson County, Ill., May 29, I 844 .

Attended the district school from school age to the age of I4.

1858-60, studied at home, under brother's instruction.

1860, attended Beloit Academy.

I 86I-5, soldier, U. S. Army.

I 866-7, attended Rush Medical College.

I 867, raised strawberries at Carbondale, Ill.

I 867-9, studied and practiced medicine under a preceptor at Makanda, Ill.

I868-70, taught school and studied science at Makanda, Ill.

I870-I, taught school and studied science at Benton, Ill. 1871, studied at Illinois State Normal University.

I87I-2, taught school and studied science at Mount Vernon, Ill.

1872-7, curator, museum of the Illinois State Natural History Society, at Normal, Ill.

I875-8, instructor in zoology, Illinois State Normal University.

I877, founded, and to I9I7, Director, Illinois State Laboratory of Natural History.

1882-I917, State Entomologist of Illinois.

I 884, Ph.D., University of Indiana.

I884-I909, professor of zoology and entomology, University of Illinois.

I886, awarded first-class medal of the Société d'Acclimatation de France, for scientific publications.

I 888-I905, Dean, College of Science, University of Illinois. I89I-2, biological expeditions, Rocky Mountains, U. S.

Fish Commission.

I893, special agent, U. S. Fish Commission; Director of the Aquarium, World's Columbian Exposition; 
Chairman, International Congress of Zoologists; President, American Association of Economic Entomologists; also prepared natural history exhibit of Illinois for Columbian Exposition.

I 894, established Illinois Biological Station.

I90I-7, President, National Society of Horticultural

Inspectors.

I905, LL.D., University of Illinois.

I908, President, Illinois Academy of Science; American Association of Economic Entomologists.

1909-2I, professor of entomology, University of Illinois. I9I 2, President, Entomological Society of America. I917-30, Chief, State Natural History Survey.

I92 I, President, Ecological Society of America. Honorary member, American Ornithologist's Union; International Congresses of Entomology; corresponding member, Academy of National Science of Philadelphia; American Entomological Society; member, National Academy of Sciences, American Philosophical Society, American Society of Naturalists, Société Entomologique de France, Loyal Legion, Sons of the American Revolution.

Died at Urbana, Ill., March I3, 1930. 


\title{
Stephen Alfred Sorheg
}

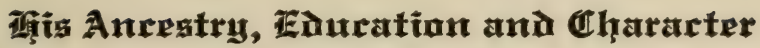

\author{
By His Son
}

\section{Ernest Browning Forbes}

Stephen Alfred Forbes WA $_{A}$ of Scotch and Dutch parentage, the receding line of his paternal ancestors in America being Isaac, John, Stephen, Aaron, Thomas, and Daniel-the first authentic record of the last-named being that of his marriage in I660 to Rebecca Perriman at Cambridge, Mass. There are plausible theories to account for the presence of Daniel Forbes at this time and place, but there are no authentic records of his origin or of his emigration from Scotland.

Of Stephen Forbes' great grandfathers three, at least, were soldiers in the Revolutionary War. These were (I) Stephen Forbes, who lived at Brookfield, and later Hardwick, Mass., and who served in a company from Hardwick and was given land in Vermont for this service; (2) Garrett Van Hoesen, a sergeant in a company of sharpshooters under General Schuyler; and (3) Capt. Isaac Sawyer, a student but not a graduate at Yale, who served with distinction in Sullivan's campaign against the Iroquois in I779.

Among the later ancestors of Stephen Forbes those who left the deepest impress were his mother, Agnes Van Hoesen, a high-strung woman, with positive likes and dislikes, and his paternal grandmother, Anna Sawyer,-said to have been unusually capable, and to have been the source of whatever intellectual abilities his generation had.

My father's family lived in the prevailing state of pioneer privation, which in their case was accentuated by the expenditure for education of their entire surplus, beyond the requirements of the barest necessities of life. When the young Stephen was obliged to give up his studies at Beloit Academy, because the last available dollar was gone, he had to take his trunk to the railroad station in a wheelbarrow. 
The house in which my father was born was built of logs, but his father was obliged to sell the farm on which this house stood, as a result of having endorsed a note for a friend, and had to begin again, on a new farm, in a house built of the slabs produced by the squaring of logs at a saw-mill. Among the conveniences of this house were a cat-hole in the door, and a knitting hole in the wall.

My father has written, "When I was ten years old my father died, and the remaining family consisted of my mother, in broken health, my youngest sister Nettie, then in her ninth year, and myself.

"We were on a farm of I 40 acres, poorly equipped and heavily mortgaged, living in a cabin of a single room, in which was a cook-stove at one end, two beds at the other, a trundle bed under one of them, and a dining table in the middle; and at one side of this building was a little "leanto' containing a single bed on which my father died.

"The only salvation of our helpless little group was my brother Henry, then twenty-one years old. He had been independent since he was fourteen, working his way to a college education for which he had prepared at Freeport and Rockford, and on which he had made about two years' progress by private study.

"Without an hour's hesitation he gave up his personal plans, abandoned his career for which he had already given brilliant promise, and took upon his own shoulders the burden of our support and education; and from that time on for the next seven years he was not our guardian merely, but he was our guardian angel.

"He saved enough on the farm to build us a comfortable home. He taught me French, sent me to Beloit to prepare for college, and helped my sister to the Woman's College at Northwestern University at Evanston; and when the Civil War broke out he sold the farm, paid off the still existing mortgage, gave my mother the residue of the family funds to live on with her eldest daughter Flavilla, borrowed the money with which to buy his horse and mine for the cavalry service, and to the war we went together, he as lieutenant and presently captain of our company, becoming later lieutenant colonel of the regiment and colonel by brevet."

$$
-\{6\}
$$


When a young boy a favorite book of my father's, and one which gave to his mind its permanent bent, was Jonathan Edwards" "A Careful and Strict Inquiry into the Modern Notions of that Freedom of the Will Which is Supposed to be Essential to Moral Agency, Virtue and Vice, Reward and Punishment, Praise and Blame." This book he seems to have had hot off the press, since it was published in I858, when my father was I4 years old, and a year later he had produced two essays on "Do Noble Things," and "The Dignity of Reason," which were academic discussions of the nature and the workings of the aspiring mind, and which obviously reflect the influence of this work by Edwards.

My father's family's interest in medicine expressed itself in the education of the eldest son, Francis, for that profession. This son was drowned when my father was 4 years old, and his own interest in medicine naturally followed. He discontinued his medical studies before their completion, however, because his savings from his career as a soldier became exhausted, and because a series of incidents having to do mainly with surgical operations without the use of anaesthetics convinced him that he was not temperamentally adapted to medical practice.

His interest in natural science was determined by an academic tradition in the family, by an agricultural background, by four years' out-of-door experience in the army, by a naturally thoughtful habit, and by a continuing scientific interest after the cessation of his medical studies.

The one older naturalist whose influence assisted him in entering the field of science was the distinguished botanist, Dr. George Vasey, whom he succeeded as curator of the museum of the State Natural History Society. He also enjoyed an early, intimate, and helpful friendship with David Starr Jordan; but in general and in all of the fields of science in which my father worked, he was his own teacher.

My father's formal education consisted of attendance at the district school from the usual age of beginning until he was I 4 years old, one year in the academy of Beloit College in I860, one year at Rush Medical College in I866-7, fol- 
lowed by one year (and part-time for a second) of office study and practice of medicine under a preceptor in I 867-9, and one term at the Illinois State Normal School in I871. The unimpressive total of these fragments gives no suggestion of the unusual breadth and depth of his education, - the open secret of which was that his attitude constituted life itself a school. Either he never went to college, or he attended continuously from age I4 to the last day of his life.

During the years I86I-65, his four-years' experience in the army constituted as intensive a course of instruction as any obtainable in college, and it was all education to the mind athirst and prepared to receive it. Enlisting in Company B of the Seventh Illinois Cavalry at the age of I7, he pursued his military studies as diligently as he had applied himself to books, and was made an orderly sergeant at 18 , a lieutenant at 19 , and captain of his company at 20. His company was on active duty during almost the whole period of the war, and he was under fire on 22 occasions including engagements at Clinton, Port Hudson, Byhalia, Moscow, Somerville, Collinsville, Okolona, Memphis, Campbellsville, Lynville, Franklin, and Nashville.

While in the vicinity of Corinth, Miss., he was captured while carrying a despatch, and spent four months in prison at Mobile, Macon, and Richmond. During this time, under desperately discouraging conditions, he maintained his morale by studying Greek; and later, after exchange, during a period of inactivity, he bought Spanish books, which he learned to read. It was all school, to the born scholar.

Of the educational value of his military experience he writes, "In one respect particularly, our experience was a hopeful prophecy, if not itself a cause, of subsequent success. Any one who had kept the solitary flame of his separate intellectual life steadily burning through all th blasts and storms of war, might reasonably believe that nothing that should happen to him thereafter could possibly extinguish it; and this, as we all know, is more than can be inferred from the completion of an ordinary college course. The eager hunger with which the students among 
us attacked the full tables at home, after four years or more of semi-starvation on a few husks and scraps, and the enthusiastic appreciation with which we embraced such long deferred opportunities as still remained to us, made it certain that no artificial graduation-day would put an end to our studies, and this, after all, is the best outcome of an education. Those of us who survived the Civil War in good health and strength, with morals unstained and minds still alert, have had no final cause to regret what seemed at the time the complete wreckage of our plans of life. To us war was not hell, but at the worst a kind of purgatory, from whose flames we emerged with much of the dross burned out of our characters, and with a fair chance still left to each of us to win his proper place in the life of the world."

In politics my father was a Republican, from the day when as a I4-year-old boy he listened to the Lincoln and Douglas debate at Freeport, Ill., on August 26, I858. He came away from this historic event "quite aflame with enthusiasm for the new Republican party and especially for Lincoln as its champion, and equally incensed against Douglas as the leader and champion of the Democrats."

Of this occasion he has written, in part:

"When Lincoln arose to open the debate, my first feeling was a genuine shock of surprise, of disappointment, of chagrin at his homeliness, his awkwardness, his plainness of attire - at the farthest remove from the bearing, look, and dress of a boy's ideal; but when he began his argument in his high, penetrating voice, calm, clear, connected, and so simple and lucid that even I could follow it without effort, I got the first impression of my life of a truly lofty character and a great mind in vigorous action.

"Lincoln, as you will remember, made the opening speech at Freeport, and although his most telling points were enthusiastically applauded, there was practically nothing in the responses of his audience to indicate that there were any Democrats among them. Douglas, in fact, opened his rejoinder with a compliment, not to the speaker for his calm and persuasive speech, but to the assembly for 'the kind and respectful attention which they yielded not 
only to political friends but to those opposed to them in politics.' He himself received at first the same kind of treatment, being even more frequently and vociferously applauded than Lincoln; but as he warmed up to his argument he began seemingly to try to irritate his opponents by calling them always 'black' Republicans, with an angry and contemptuous emphasis on the word 'black.' The taunt was received in silence for a few times, and then loud cries of 'white, white,' began to come from all directions, every time he used the offensive epithet, and the clamor presently became so great, after a peculiarly irritating application of it, that Douglas paused to remind his hearers 'that while Lincoln was speaking there was not a Democrat vulgar and blackguard enough to interrupt him.' It was at this point that my adhesion to republicanism became complete, and I shouted up to Douglas at the top of my boyish voice: 'Lincoln didn't use any such talk.' I was sharply reproved by those about me, and told that I must not 'talk back'; and so stood in mortified silence until Lincoln again took the stand, when he began by saying: "The first thing I have to say to you is a word in regard to Judge Douglas's declaration about the "vulgarity and blackguardism" in the audience, .... that no such thing, as he says, was shown by any Democrat while I was speaking. Now, I only wish, by way of reply on this subject, to say that while $I$ was speaking, $I$ used no "vulgarity or blackguardism" toward any Democrat.' With this elaboration of my own sentiment I need not say that I was relieved and delighted, or that I joined in the hearty laughter and applause with which ..... his rejoinder was received."

As a Republican, however, my father was, as in most other ways, an independent, and he never hesitated to "scratch" his ticket in favor of the Democrat when he believed the Democrat to be the better man.

My father's religious status is made clear by the following, which was written in I923: "I was, and still am, a rationalist and an agnostic, for whom what is known as faith is merely assumption, often practically necessary, since in active life one must very often act as if he believed 
what he does not and cannot really know, but unexcusable in purely theoretical matters,"-but he drew a line through the words "and still am," and wrote above them the words "as a younger man." I think that this change was dictated by a growing hope that there is more to life than a scientist knows, or can know. At this time he was much attracted by the beauty and the comfort of the orthodox beliefs of his childhood, which he had lost during his scientific career.

Throughout life my father was active in the support of liberal religion, and, with my mother, initiated the movement which resulted in the establishment of the Unitarian Church of Urbana.

My father was reticent concerning his inner and deeper life, and, in I923, in writing of things he would do differently if he were to live again he said, "I would be open, frank, and free with respect to my theories of life, and especially of religion, instead of leaving my children, so far as I was concerned, to find their own way in these difficult and important matters, as best they individually could. It was not indifference or thoughtlessness that influenced me, but, for one thing, a belief in individual freedom in this field, unprejudiced by authority exercised upon the helpless and defenceless child, and for another a conviction that my personal views were so far out of harmony with those of the ordinary American community that my children might find themselves strangers and even outcasts among their fellows if they were to follow my lead."

Physically, my father was characteristically restless, active, and energetic. While at the height of his powers his course through the Natural History Building could be traced by the slamming of the doors behind him. The attitude of command, attained during his extensive military service, was habitual, and he expected action on the part of his subordinates.

Until the last few years he exercised with phenomenal persistence. In the early days he did a great deal of walking, running, rowing, wood-chopping, club swinging, rollerskating and horse-back riding. He rode a bicycle for many years, and averred that his use of this vehicle added ten years to his life. 
Later he drove an automobile and became locally famous for a long series of minor mishaps,-resulting from the facts that the automobile came late in the period of his physical adaptability, and that he drove to the accompaniment of his intensely concentrated thinking, without knowing that he failed to give the job his whole attention.

He learned to skate, swim, and to play golf with the generation following his own, but did not become proficient in these exercises. "Common" labor was uncongenial to him, and he once said that, for him, it would be "like hitching a race-horse to a dump cart."

Mentally he was quick, acute and alert; he delighted to deal with nice distinctions, and especially with complicated situations; and had a decided predilection for statistical and graphic presentation of products of research.

He was a poor sleeper, about five hours being his normal amount. The remainder of the night he spent reading, in bed.

He was throughout life a prodigious reader, of a wide range of serious literature. When delving into treatises in the fields of philosophy, ethics, psychology, pedagogy, metaphysics, genetics, scientific theory, and the method of science, his mind was enjoying its choicest diet; and by way of lighter reading he devoured quantities of French fiction.

Temperamentally he was in all ways a man of refined sensibility. He had a developed appreciation of the dramatic, and greatly enjoyed the theatre. His soul was attuned to the poetic, and he was devoted to Browning. When deeply moved he occasionally wrote an exquisite poem - to express himself - and then, characteristically, destroyed it. He loved music, and he played the organ in the days before pianos were common. He was naturally imaginative, and by early training was deeply religious.

A prominent influence throughout his youth and young manhood was his love for his sister Agnes Vernette-called Nettie-who was unusually affectionate, idealistic, and religious, and who had withal a lightsome and charming humor. There is real literature in the outpourings of these two rare and kindred souls, in their extensive correspondence. 
As a lover my father was ardent and romantic, and his own account of his falling in love with the one who was to become his wife is here recorded for its revelation of character:

"I was protected and preserved for the time when my predestined fate should overtake me by a mingling of a rather fastidious taste in girls and a mortal shyness in the presence of any one of them. An attractive girl was, to me as a youngster, a being of another order than myself, mysterious, adorable, and unapproachable, and I both envied and despised the boys who met them familiarly and who treated them as merely equal to, or only a little better than, themselves.

"My absence from normal civil life from the age of seventeen to twenty-one, when other young men were finding their places in a mixed society, was no doubt a heavy handicap; and for years after my return from the army I was absorbed in study under difficulties so serious that I had no leisure or abiding interest in anything else, and I was thus kept immune to any dangerous infection until these quarantine barriers all came tumbling down in I87I. I first met your mother when she was a senior student in the State Normal School and I was principal of the public schools at Mt. Vernon in southern Illinois. In our first interview I tried to engage her as a teacher in the high school there; and I remember her next as an occasional visitor to the Zoological Museum at Normal of which I was made curator in 1872 . Then came the fateful evening when we met at one of the houses in the little town. Many people were there but I saw only her, with her blue eyes, her brown hair, her complexion of pale ivory with a delicate tint of rose on her cheek, her white lawn dress with flowing sleeves, her pretty hands and plump round arms, bare to the elbows. The sweet kindness of her look and bearing made it easy to talk to her, and I ought to have seen her home, but I did not dare to take the risk. Indeed I did not need to, so far as I was concerned, for she went with me to my room, a captivating image, floating in the air before me, and I realized then I was in love." 
Within the family my father expressed himself with freedom-except on the matters which lay next his heart. He was fond of his children, and always attentive to their interests. His beautiful devotion to our mother was a continuing inspiration to all of us.

In my father's business relations he was courteous, sympathetic, and uncommonly patient with human imperfection. Since he was of a sensitive disposition he avoided contentious and embarrassing situations if he could properly do so; but he had a command of spoken English equal to his distinguished literary style, and if a business relation demanded complete frankness he had this quality at his disposal.

Since he was of an intensely intellectual type, he was easily bored by boresome people, and made but few intimate friends. There was, however, almost always some small and choice group of kindred spirits with whom he met for feasts of philosophy, and these men he enjoyed immensely.

During his later years, as his professional interests became more perfectly organized, and more securely established, my father was able to relax a certain degree of the pressure under which he had formerly worked, and to enjoy knowing a greatly broadened group of acquaintances. These years, therefore, were increasingly rich in gratifying personal relations.

It is characteristic of the man that even among his closest friends he was fair and temperate in his expressions regarding those whom he disapproved. He was much too wise to let himself hate anyone. On occasion, however, he could demonstrate a power of description equivalent to vivisection.

The dominant motive in my father's life was overwhelmingly that of scientific research in the public service. Research was, with him, not a conscious passion, I think; it was life itself-as natural as breathing; and his publicmindedness was no less spontaneous. It is true that he managed the investment of his savings with great interest but to have been condemned to a life devoted to private gain would have been for him genuine imprisonment. 
The final, supreme demonstration of his superb morale was when with health, strength, friends of his own age, and wife all gone, he was able, through sheer intellectuality, to continue at his work, stimulated by the doing of new things, in the true spirit of youth, until 9 days from the date of his death, at the age of 85 years, 9 months, and I3 days. 


\section{The Oriter af the Serutes}

Processional-"Funeral March on the Death of a Hero". Beethoven

Quartet-"For All the Saints"........................nby

Prayer and Address

Reverend Edward D. Johnson

Pastor, Unitarian Church, Urbana

Quartet-“Lead Kindly Light" (Newman) ............ Dykes

Address

Professor Harley Jones Van Cleave, Ph.D.

Address

Dean Kendric Charles Babcock, Ph.D., LL.D.

Address

David Kinley, Ph.D., LL.D.

President of the University

Benediction

Quartet-“Nunc Dimittis".............................

Recessional-“Funeral March"...................... 


\section{Honorary Pallbearers}

Representing the National Academy of Sciences

Professor William Albert Noyes, Ph.D., Ll.D., Chem.D., D.Sc.

Representing the Illinois Academy of Science

Professor Charles Frederick Hottes, Ph.D.

Representing the University, the official, and the personal connections of Professor Forbes:

Honorable George Andrew Barr, A.B., President of the Board of Trustees

Honorable William Lamont Аввотt, M.E., LL.D., Former President of the Board of Trustees

Honorable Robert Franklin Carr, B.S., LL.D., Former President of the Board of Trustees

Honorable Michael F. Walsh, Director of the State Department of Registration and Education

The Council of Administration of the University

President David Kinlex, Deans Thomas Arkle Clark,

Kendric Charles Babcock, Arthur Hill Daniels, Charles Ernest Chadsey, Charles Manfred Thompson, Herbert Windsor Mumford, Milo Smith Ketchum, Albert James Harno, Maria Leonard, David John Davis, William Baker Day and Frederick Bogue Noyes

Professor Emeritus Charles Wesley Rolfe, M.S.

Professor Emeritus Arthur Newell Talbot, C.E., D.Sc.

Professor Emeritus Herbert Jewett Barton, A.M.

Professor Emeritus Eugene Daven port, M.Agr., D.Sc., LL.D. Professor James McLaren White, B.S., Supervising Architect Professor Emeritus Oliver Albert Harker, A.M., Ll.D.

Professor Emeritus Edgar Jerome Townsend, Ph.D., LL.D. Professor Emeritus William Trelease, D.Sc., LL.D.

Honorable Francis Grant Blair, B.S., LL.D., State Superintendent of Public Instruction

President Livingston Chester Lord, A.M., LL.D., Eastern Illinois State Teachers' College 
Professor Henry Chandler Cowles, Ph.D., Sc.D., Chairman of the Department of Botany, University of Chicago

Professor Emeritus Stanley Coulter, Ph.D., LL.D., Former Dean of the School of Science and of Men, Purdue University

Professor Edson Sunderland Bastin, Ph.D., Professor of Economic Geology, University of Chicago

President Emeritus Edward Asahel Birge, Ph.D., LL.D., Sc.D., University of Wisconsin

President Emeritus David Starr Jordan, M.D., Ph.D., LL.D., Leland Stanford University

Leland Ossian Howard, Ph.D., LL.D., Sc.D., Chief, Bureau of Entomology, United States Department of Agriculture, Washington, D. C. 


\section{Active Pallbearers}

Dean Arthur Hill Daniels, Ph.D.

Professor Samuel Wilson Parr, M.S., D.Sc.

Professor Charles . Tobias Knipp, Ph.D.

Professor Morris Morgan Leighton, Ph.D.

Professor Arthur Moses Buswell, Ph.D.

Professor Charles Zeleny, Ph.D.

\section{USHERS}

Wesley Pillsbury Flint, B.S.

Theodore Henry Frison, Ph.D.

Pressley Adams Glenn, A.M.

Charles Edwin Janvrin, Ph.B., B.L.S.

Clell Lee Metcalf, D.Sc.

Henry Carl Oesterling, A.B.

Victor E. Shelford, Ph.D.

Leo Roy Tehon, A.M.

David Hiram Thompson, Ph.D. 


\section{OPpnting Sentenerg}

\section{Reverend Edward D. Johnson}

"The righteous shall be in everlasting remembrance" ${ }_{1}$ and "the memory of the just is blessed."

"As we have borne the image of the earthy, we shall also bear the image of the heavenly." 3 "For this corruptible must put on incorruption, and this mortal must put on immortality. So when this corruptible shall have put on incorruption, and this mortal shall have put on immortality, then shall be brought to pass the saying that is written, Death is swallowed up in victory. O death, where is thy sting? O grave, where is thy victory?"'
"Above the requiem, 'dust to dust'
Shall rise our psalm of grateful trust
O happy they in God who rest
Living or dying they are blest."

"And thus the man died leaving his death for an example of a noble courage, and a memorial of virtue not only unto young men, but unto all his nation."

"We know in part and we prophesy in part. But when that which is perfect is come, then that which is in part shall be done away." "For now we see through a glass darkly; but then face to face: now I know in part; but then shall I know even as I am known." 6

Among the papers of Dr. Forbes there was found after his death one which bore, penciled in his hand-writing and signed with his initials, the following lines:

He is not old who loves the young,

Whom the young love is young himself,

The full heart is the happy one.

1Psalms I I 2:6

${ }^{2}$ Proverbs 10:7

3I. Corinthians I 5:49

${ }^{4}$ I. Corinthians $15: 53-55$

I. Corinthians 13:9-10

${ }^{6}$ I. Corinthians $13: 12$ 
May the full heart-the curious mind,

Be yours until your latest day.

Then shall your age be fresh as youth,

And late December bloom like May.

$$
\text { S. A. F. }
$$

So was it - as his wish was-

"Calmly, calmly lay him down!

He hath fought a noble fight;

He hath battled for the right;

He hath won the fadeless crown.

"All that makes for human good, Freedom, righteousness and truth

These the objects of his youth,

Unto age he still pursued.

Hoping-trusting, lay him down!"

\section{-William Gaskell}

\section{"Formed on the good old plan,}

A true and brave and downright honest man!"1

"Who is the happy Warrior? Who is he That every man in arms should wish to be? - It is the generous Spirit, who when brought Among the tasks of real life, hath wrought Upon the plan that pleased his boyish thought: Whose high endeavors are an inward light That makes the path before him always bright: Who, with a natural instinct to discern What knowledge can perform, is diligent to learn;

-Who, if he rise to station of command Rises by open means; and there will stand On honourable terms, or else retire, And in himself possess his own desire; Who comprehends his trust, and to the same Keeps faithful with a singleness of aim;

'J. G. Whittier, "Daniell Neall." 
-And, through the heat of conflict, keeps the law In calmness made, and sees what he foresaw; - He who, though thus endued as with a sense And faculty for storm and turbulence,

Is yet a Soul whose master-bias leans

To homefelt pleasures and to gentle scenes;

Who, with a toward or untoward lot, Prosperous or adverse, to his wish or notPlays, in the many games of life, that one Where what he most doth value must be won:

Whom neither shape of danger can dismay,

Nor thought of tender happiness betray;

Who, not content that former worth stand fast, Looks forward, persevering to the last,

This is the happy Warrior, this is $\mathrm{He}$

Whom every Man in arms should wish to be." 1

"The longer on this earth we live

And weigh the various qualities of men,

Seeing how most are fugitive,

Or fitful gifts, at best, of now and then,

The more we feel the high stern-featured beauty

Of plain devotedness to duty,

Steadfast and still, nor paid with mortal praise,

But finding amplest recompense

For life's ungarlanded expense

In work done squarely and unwasted days.

His was the true enthusiasm that burns long,

Domestically bright,

Fed from itself and shy of human sight

The hidden force that makes a lifetime strong,

Modest, yet firm as Nature's self; unblamed Save by the men his nobler temper shamed; Never seduced through show of present good

${ }^{1}$ William Wordsworth, "Character of the Happy Warrior." 
By other than unsetting lights to steer

New-trimmed in Heaven, nor than his steadfast mood

More steadfast, far from rashness as from fear;

Rigid, but with himself first, grasping still

In swerveless poise the wave-beat helm of will;

Placid completeness, life without a fall

From faith or highest aims, truth's breachless wall,",

"He widened knowledge and escaped the praise;

He wisely taught, because more wise to learn;

He toiled for Science, not to draw men's gaze,

But for her lore of self-denial stern.

That such a man could spring from our decays

Fans the soul's nobler faith until it burn." 2

\section{Prayer}

Lord's Prayer

"The hoary head is a crown of glory, if it be found in the way of righteousness." ${ }^{3}$

"Thine age shall be clearer than the noonday; thou shalt shine forth, thou shalt be as the morning." 4

"Well done, good and faithful servant: . . Enter thou in to the joy of thy lord."

1James Russell Lowell, "Under the Old Elm."

${ }^{2}$ James Russell Lowell, "Jeffries Wyman."

${ }^{3}$ Proverbs $16: 31$

4Job I I : 17

5Matthew 25:2I 


\section{Stephen Alfren Furbes as a Srientigt}

\section{Professor Harley J. Van Cleave, Ph.D.}

For twenty years I have been a close student of the scientific works of Stephen A. Forbes. Yet this fifth of a century runs concurrently with but a paltry third of the total span of his sixty years of productive scholarship. With a filial admiration and an ever-expanding professional interest, I have frequently handled the more than five hundred cards which accession his published contributions to science. Now comes the opportunity to summarize in a few words for myself and my colleagues an evaluation of these contributions which sixty years of arduous labor have engraved upon the scroll of scientific attainment.

Stephen Alfred Forbes has been in turn a prophet, priest and patriarch of three succeeding generations of scientists, making profound contributions in each generation in rapidly changing fields, and portraying a mind eternally youthful. Not content with following the trends in his chosen sciences, he to the end assumed a vigorous leadership in opening and developing new lines of investigation. Each of the three generations has proudly proclaimed him as its own and has pronounced his contributions as sound, thorough, intensive, and even frequently prophetic.

The breadth of his interests and depth of his understanding are not attainments of an ordinary intellect. In the present generation, the average man of science finds it imperative to choose some limited or restricted field for intensive work if he has ambitions to become recognized as an authority. While Professor Forbes had the breadth of interest of the naturalist of two generations ago, he contributed materially to the development of several distinct modern fields of research, becoming recognized as a founder of more than one of the modern branches of the biological sciences. 
Self-tutored, ${ }^{1}$ his development and his researches lacked the limitations often imposed by a feeling of personal obligation to follow in the path prescribed by a teacher. $\mathrm{He}$ was thus free to discover and to concentrate upon the unsolved problems in the whole realm of animate nature. His was the good fortune, the sound judgment, and the magnetic power of leadership to draw to himself strong associates of diversified interests, thus enabling him to organize and conduct research ventures of unusual scope. As an organizer and director of extensive investigations, covering highly diversified aspects of broad problems, Professor Forbes brought to these projects a forceful leadership which is reflected in the unity and completeness of his studies in collaboration with members of his staff.

Standing ever at the borderline of the pure and the applied aspects of his chosen sciences, he brought forth contributions which have the distinctive merit of combining the most thoroughly sound scientific results with practical applications of his discoveries to the betterment of man's relationship with animate nature.

Very early in his program, he became impressed with the significance of interrelationships between organisms and their environment. Before ecology had been conceived as an offspring of the biological sciences, Professor Forbes had adopted the ecological point of view in his published writings. As early as 1887 , in a spirit of prophetic anticipation of the coming ecological era in North America, he delivered a paper on The Lake as a Microcosm, wherein he set forth the themes of interdependence of organisms and community of interests in aggregations of living beings. This ecological point of view has dominated his entire program of research. His contributions on insects, as well as those on fishes and on birds have been conceived in light of relationship to the environment and have always acknowledged man and human interests as essential though by no means exclusive factors of importance in the environment of organisms. As a consequence,

IIn a private conversation, Professor Forbes once told me, "I have never, in University or Normal School, received an hour of formal instruction in any one of the subjects that I have taught." 
even his economic studies have been engendered in that breadth of biological interpretation that renders them distinctive in their field.

In his pioneer work on the food of birds, of fishes, and of insects, he contributed a wholly new method of attack upon problems in the interpretation of the economic status of animals. Many and marked have been the tributes paid him by subsequent workers in recognition of the importance of these pioneer studies.

His early interest in the food of birds in its relation to their economic importance, found an extension in later years to a numerical study of birds in different localities. Thereby he sought a more exact means of interpreting the true value of birds in relation to agriculture.

The long series of papers on the biology of the Illinois River, stands as one of the greatest monuments to Professor Forbes. These investigations, starting in I894, were carried on under his leadership with the collaboration of Frank Smith, C. A. Kofoid, and R. E. Richardson, whose names will be perpetually associated with that of S. A. Forbes. Intensive work on the life of the Illinois River and correlation of physical conditions with distribution of life of the stream were carried on for a long period of years. When changed conditions made a continuation of this project seem unprofitable the researches had extended to that point where it was widely acclaimed that the Illinois River had been more thoroughly investigated as to its biology than any other river in the world.

From his earliest studies Professor Forbes was constantly confronted with undescribed animals about which he could not write intelligently, without first naming them. He became recognized as a systematist chiefly because of his works with insects, fishes, and crustaceans, yet his personal attitude toward his own work never yielded to that spirit of petty jealousy which has marked many systematists. He formulated descriptions with unrivaled exactness, calling upon those powers of expression which have always distinguished his writings. After a description was once published it stood upon its own merits. Even when species which he established became erron- 
eously disregarded by subsequent workers he, at least in some instances, withdrew from the controversy and allowed later investigators to discover the error and to reestablish his original names.

Much of his earliest work was upon the fresh water crustacea which at the time when he began his studies were practically unknown in this country. A colleague, C. Dwight Marsh, an internationally recognized authority in this group, has evaluated Professor Forbes' earliest taxonomic studies with the statement: "In North America articles were published regarding some forms in the early part of the century, but nothing recognizable appeared until S. A. Forbes commenced his series of papers. Although these papers were not extensive, they were exact and carefully worked out, and to Forbes may be given the credit of laying the foundation for all subsequent work in this country."

Some notion of the thoroughness of his studies may be gained from the fact that a paper which he published in I 876 is the most comprehensive work on the higher crustacea of Illinois which has appeared down to the present date. When Professor Forbes was accorded that signal honor of membership in the National Academy of Sciences, the significance of this early period of his work that had escaped the memory of many of his associates was again brought to light.

During the period from I 882 to I92I when he maintained a separate office as State Entomologist, and personally directed the work of a corps of research workers, his reports upon economic insects and their control exerted a powerful influence upon the agricultural development of the State. At the same time, his investigations in economic entomology were conceived in an appreciation of biological principles which has added to them a guarantee of permanency in the biological literature that could not have been accorded the announcement of mere remedial measures in agricultural practice against insect pests.

Early in the course of his investigations of the fauna of the State he projected a plan of publishing current investigations looking toward the preparation of final mono- 
graphic reports on the animal life of the State. His extended studies on fishes, culminating in that monumental report on the Fishes of Illinois in collaboration with R. E. Richardson, is widely cited as a model for similar studies. At the time of its publication in 1908, it represented a more thorough and more comprehensive survey of the fish fauna of Illinois than had been available for any similar region of our country.

In this brief attempt at an evaluation of Professor Forbes' contributions as a scientist, I have touched upon only those fields in which he personally made tangible contributions. His influence far transcends these bounds. As a teacher and as a champion of the cause of science in education, the results of his efforts have passed unquestioned.

Late in life, when most men would have cherished the opportunity of gracefully drawing to a close the work already in progress, he became an active and ardent advocate of a program of scientific forestry for the State and but recently was responsible for the establishment of a plant disease survey within his own state organization. These new interests reflected the operation of an intellect undulled by time and to the end keen in its appreciation of the opportunities and obligations of science.

Thorough, deep, intensive, uncontentious, all of his contributions to science are heaped with that measure of unassuming, generous attitude which he carried into his every activity as an inseparable quality of his personality. 


\section{Antregs}

Dean Kendric Charles Babcock, Ph.D., Ll.D.

A profound sense of loss and a sentiment of mourning inescapably dominates our minds and hearts as we mark in this simple and solemn manner the death of Stephen Alfred Forbes, our admired colleague, wise counselor, and beloved friend. Through four and a half decades of highly energized relations to the University and the State he has been almost uninterruptedly among us. Yet in this sadness, in the very strains of the funeral march, there is surely a resurging major note of exaltation and thankfulness that forty-five of Professor Forbes' eighty-six years were lived here, richly, always actively, and nobly contributive to the common good. We have watched with ever increasing favor and confidence his unostentatious diligence as a scientist, and the contagious energy with which he sought to reinforce and build up the higher life of the State through education, health, and conservation of natural resources. He was of Illinois; his work was done in Illinois. A devoted, far-seeing, resourceful and tireless worker for her welfare, he was at once a teacher, a great biologist, an inspiring director of younger investigators, a writer whose felicitous expression and clarity carried conviction to the public mind.

His simplicity, his eager and original curiosity in the fields of science, his determination to get to the bottom of things call to mind the quaint verses which Henry Wadsworth Longfellow wrote in celebration of the fiftieth birthday of another great leader of science, Louis Agassiz, in 1857 :

And Nature, the old nurse, took

The child upon her knee

Saying: "Here is a story-book

Thy Father has written for thee. 
"Come wander with me," she said,

"Into regions yet untrod;

And read what is still unread

In the manuscripts of God."

And he wandered away and away

With Nature, the dear old nurse,

Who sang to him night and day

The rhymes of the Universe.

And whenever the day seemed long,

Or his heart began to fail,

She would sing a more wonderful song,

Or tell a more wonderful tale.

So she keeps him still a child,

And will not let him go.

Professor Forbes came to the University of Illinois in I884, to a little institution in a small rural town and labored in it creatively through all its amazing growth since that time. He was professor of zoology and entomology continuing his dual function until I909 when he became professor of entomology alone. In I92 I he resigned, accepting the title of Professor Emeritus. Through these years he was also devoting part of his time to the State Laboratory of Natural History or its successor in the State government, but always with a unity of thought and purpose and a variety of method which revealed again and again his greatness and his prophetic vision. For seventeen of these busy and productive years he served as dean of the College of Natural Science, or Science, moulding with a skillful hand the development of that important division of the University, while his individual investigations and original contributions to land and water biology placed him high among scientists and added prestige to the University:

His colleagues in the faculty and in the University administration renew their expression of gratitude and obligation for his years of exacting labor as chairman of the 
most important committee of the faculty of the whole University, the Senate Committee on Educational Policy. His poise, penetration, high common sense and sagacity in dealing with the complex and often critical problems of a rapidly growing State University were assurances of patient consideration and practical wisdom. The heritage of his example and the kindliness of his personal relations in the University and the State are precious possessions of two generations of the men and women of Illinois. 


\section{Aniregs}

President David Kinley, Ph.D., LL.D.

My acquaintance with Professor Forbes began immediately on my arrival at the University in 1893 . He was one of the older men who welcomed me as a young newcomer and attracted me immediately to himself, as he always attracted others, by his kindly personality, his high attainments, his brilliant intellect, and his inspiring influence. In the development of the work of my department in those, its first days, no one at the University was more helpful. His wide range of knowledge, his just estimate of the relative importance and the relations of various subjects of study, were a constructive influence on my work through many years. In many ways he prevented me from making mistakes. By his sound judgment and keen insight he often checked my youthful enthusiasm and kept my feet on the ground. And so I have honored and trusted and loved him through the years, and have sought and followed his counsel even down to the present time.

Professor Forbes not only was distinguished for his accomplishments in the special field of science that was his chosen life work, but was very remarkable for the variety of his intellectual interests, the wide range of his knowledge, his depth of insight into a great number of subjects, the clearness of his thinking, and the lucidity of his expression. He was a master of literary style, writing with a simplicity and clarity that would serve as a model for many specialists in literature and rhetoric. His success and distinction in his specialty rested upon a broad foundation of general culture which he laid early in his career and constantly widened and deepened throughout his life by his general reading. No subject in the field of knowledge was foreign to him. General literature, art, history, the social sciences, philosophy, psychology, foreign languages,-all were related by him to his own work as occasion required or as opportunity to help others offered. He 
knew something of the classics, of German, French, Spanish, Italian and Russian. I have never known any other specialist so remarkable in this respect.

Professor Forbes was undoubtedly the pioneer in securing the introduction of the study of the natural sciences in to the educational system of Illinois. His efforts in this line began before he came to the University, at a time when the natural sciences were looked on askance by educational authorities. As a result very largely of his influence they received due attention and became a substantial part of the general educational program. As an educator and member of a university faculty he believed in keeping the door of opportunity open to all. A way to climb to a higher education, he once said, should be open to every boy and girl by some route,-whether a knotted rope, a ladder or a broad highway. Professor Forbes was not an educational or scientific partisan. The catholicity of his views led him to give a hearty welcome to every new subject of study that promised to add to human knowledge. More than that, as I have said, he became a student of many of these in order that he might have a better understanding of their subject matter and their relation to other studies.

Two outstanding characteristics of Professor Forbesmarks of a great soul and mind-were his tolerance and open-mindedness. He was patient with the ignorant and the stupid; he listened with a smile to the dogmatic and the self assured; and he quietly tempered the ardor of the over-enthusiastic claimant of scientific progress and discovery, by reminding him that knowledge was ever growing and that "assured facts" of today might be discarded tomorrow.

He would listen to all views and facts advanced as new and change his own opinions to conform to established new truth,-always keeping in mind the thought that nothing can be determined as final until the evidence is all in.

Many students and writers owe their success fundamentally to him. When James Harvey Robinson wrote his "Humanizing of Knowledge" he sent Professor Forbes 
a copy on the fly-leaf of which he wrote: "Once there was a youngster who fell under your influence and looked through the high Swift binocular and incidentally damaged the favorite tenth-inch objective and never'fessed up until he was nearly sixty-one years old. A long time after you set his feet in the paths of science he was asked by a committee of the A. A. A. S. to talk at Salt Lake City and this little book is all your fault, dear Professor Forbes.James H. Robinson."

With the universality of talent that characterized him, Professor Forbes would have become distinguished in any line of intellectual work that he might have taken up. He wrote English better than most writers. He knew his history and social sciences better than many of those whose specialties they are. He had a deeper knowledge of the human mind and heart than many psychologists and clergymen. He would have been successful as a diplomat and by the simplicity, clarity, and honesty of his thinking would have won a large following if he had gone into public life.

Professor Forbes was known abroad for his scientific work even better than he was here. Every great biological scientist in the world and men great in many allied lines knew Professor Forbes' name and work even if they had not met him personally. I recall going into a biological laboratory in a European country more than twenty years ago and on saying that I was connected with the University of Illinois I heard another great zoologist exclaim, "Oh, yes! That is where Professor Forbes is. I know his work in such and such a field."

One of the illustrious founders of the scientific greatness of the University of Illinois; one of its great teachers; one of its influential administrators; one of the number of its staff who by their discoveries have promoted the economic welfare of the people of the State; adviser both of the State and National Governments on matters of scientific and economic importance; accomplished scholar; loyal friend; genial companion-Professor Forbes was all of these. Moreover, he had that spirit of scientific humility which led him to respect the work of others and to see 
clearly the fallacy of assuming that he or the scientific world had yet learned all that is to be learned about the Universe. He had, therefore, a deeply religious spirit and while he never permitted his freedom of thought to be limited by the language of any special creed he was reverent, tolerant, spiritually buoyant, and hopeful that life does not end here.

And so "the man, that with me trod

This planet, was a noble type;

That friend of mine who lives in God."

And so, Stephen Forbes, on your bier today we lay a wreath of laurel, the victor's reward of your great achievements as a scientist; we lay a wreath of roses, as evidence of our love; we lay there, too, in grief, a spray of asphodel in mute testimony of our sense of loss and our sorrow for your parting.

We "leave thy praises unexpressed

In verse that brings ourselves relief, And by the measure of our grief

We leave thy greatness to be guessed;

So here shall silence guard thy fame;

But somewhere, out of human view, Whate'er thy hands are set to do Is wrought with tumult of acclaim." 


\section{Aluste Sung at the Seruters}

Quartet

Mrs. Marion Treleaven Thomas, Soprano

Miss Kathryn Janie Sutherlin, Contralto

Mr. Frank T. Johnson, Tenor

Prof. Arthur Beresford, Bass

Director Frederic B. Stiven, at the organ

For All The Saints

For all the saints, who from their labors rest, Who thee by faith before the world confessed, Thy name, O Jesus, be forever blessed,

Hallelujah, Hallelujah!

Thou wast their rock, their fortress, and their might;

Thou, Lord, their captain in the well-fought fight;

Thou, in the darkness drear, their one true light.

O blest communion, fellowship divine!

We feebly struggle, they in glory shine;

Yet all are one in thee, for all are thine.

The golden evening brightens in the west;

Soon, soon to faithful warriors comes thy rest;

Sweet is the calm of Paradise the blest.

$-W . W$. How

\section{Lead Kindly Light}

Lead, kindly Light, amid th' encircling gloom,

Lead thou me on!

The night is dark, and I am far from home;

Lead thou me on!

Keep thou my feet; I do not ask to see

The distant scene; one step enough for me. 
I was not ever thus, nor prayed that thou

Shouldst lead me on;

I loved to choose and see my path; but now

Lead thou me on!

I loved the garish day, and, spite of fears, Pride ruled my will. Remember not past years!

So long thy power hath blest me, sure it still Will lead me on

O'er moor and fen, o'er crag and torrent, till

The night is gone

And with the morn those angel faces smile,

Which I have loved long since, and lost awhile!

-John H. Newman

\section{Nunc Dimittis}

Lord, now lettest thou thy servant depart in peace according to thy word. Amen! 


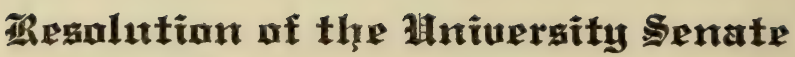

The Senate of the University of Illinois recognizes in the death of Stephen Alfred Forbes, on March eighth, the grievous loss which the University, the State, and the larger world of science has suffered. It enters upon its permanent records this formal memorial evidencing the great esteem in which he has been held throughout his long and distinguished career of widely varied activities as a citizen, a soldier, teacher, administrator, public leader and scientist.

When he retired as Professor Emeritus of Entomology, in I92I, he had been a full professorial member of the Senate for thirty-seven years. He was an original and stimulating teacher and a resolute and versatile investigator to the very end of his life. He was not one who thought his duty to the University began and ended in the classroom.

The introduction of Nature Study in to the schools of the State and the inclusion of courses in Biology in the curricula of the high schools were due to his initiative, working in close association with Professor Burrill.

He was always actively engaged in extending the bounds of knowledge in the most varied fields and from his success as an investigator grew the organization and development of the State Natural History Survey until it has become one of the most effective agencies of its kind in the world.

The Senate knew him as Professor of Zoology and Entomology and Dean of the College of Science; it admired his sagacity and patience as chairman of its Committee on Educational Policy; its members loved him for his simplicity, sincerity and broad human interests. The University and the State are immeasurably indebted to him as one of their most useful and eminent laborers for the common good.

April 7, I930

$$
\text { H. J. Barton }
$$




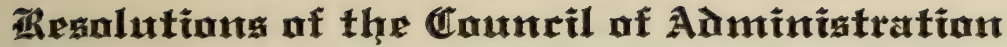

The Council of Administration of the University of Illinois here records its deep sense of obligation to Stephen Alfred Forbes for his wise judgment and willing coöperation with the faculty and administrative officers of the University through a remarkable period of service stretching from I 884 to the present year. Both in the teaching of biological science to more than nine generations of University students, and in the unremitting and far-sighted promotion of scientific investigation, his career as a scientist in the University and throughout the State has probably no parallel in the history of Illinois.

In I 884 he became Professor of Zoology and Entomology; in 1909 he was appointed Professor of Entomology in a separate department, retaining this position until he resigned and was made Professor Emeritus in I92I. Beginning in I888, for seventeen of these busy and highly productive years, he was Dean of the College of Science.

For many years he directed, as Chairman, the work of the Senate Committee on Educational Policy, perhaps the most important committee of the faculty. To his ability, poise, sagacity, and progressive thought may be attributed much of the educational advancement which the University has made. The Council acknowledges this service to the University with abiding gratitude. Throughout all the years of his labors for the University and for the State, he steadily increased the respect, confidence, and affection of those who were privileged to work with him.

Thomas Arkle Clark Secretary

March I8, 1930 


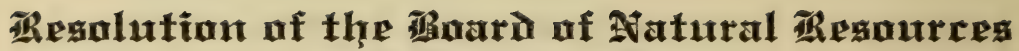 ani congeruation}

Resolved: That the Board of Natural Resources and Conservation of the State of Illinois records its realization of the great loss sustained by his immediate associates, the Commonwealth, and the scientific world, in the lamented death of Professor Stephen A. Forbes, late Chief of the Natural History Survey Division of the State work under the supervision of this Board; that this resolution be entered upon the minutes of the Board; and that its contents be communicated by the Secretary to the family of Professor Forbes.

April I, I930

W. A. Noyes

Secretary

\section{THE LIGRABजy OT THE UNIVERSITY OF ILLINOIS}





\section{1}

